Article

\title{
Assessing Sustainable Urban Development Trends in a Dynamic Tourist Coastal Area Using 3D Spatial Indicators
}

\author{
Teresa Santos ${ }^{1, *(1)}$, Raquel Deus ${ }^{1}\left[\right.$, Jorge Rocha ${ }^{2} \mathbb{(}$ and José António Tenedório ${ }^{1}(\mathbb{D}$ \\ 1 Interdisciplinary Centre of Social Sciences (CICS.NOVA), Faculty of Social Sciences and Humanities \\ (NOVA FCSH), Universidade NOVA de Lisboa, Avenida de Berna, 26-C, 1069-061 Lisboa, Portugal; \\ r_deus@fcsh.unl.pt (R.D.); ja.tenedorio@fcsh.unl.pt (J.A.T.) \\ 2 Centre for Geographical Studies, Institute of Geography and Spatial Planning, Universidade de Lisboa, \\ 1600-276 Lisboa, Portugal; jorge.rocha@campus.ul.pt \\ * Correspondence: teresasantos@fcsh.unl.pt
}

check for

updates

Citation: Santos, T.; Deus, R.; Rocha, J.; Tenedório, J.A. Assessing Sustainable Urban Development Trends in a Dynamic Tourist Coastal Area Using 3D Spatial Indicators. Energies 2021, 14, 5044. https:// doi.org/10.3390/en14165044

Academic Editors: Nuno

Carlos Leitão and

Luis Hernández-Callejo

Received: 4 June 2021

Accepted: 3 August 2021

Published: 17 August 2021

Publisher's Note: MDPI stays neutral with regard to jurisdictional claims in published maps and institutional affiliations.

Copyright: (c) 2021 by the authors. Licensee MDPI, Basel, Switzerland. This article is an open access article distributed under the terms and conditions of the Creative Commons Attribution (CC BY) license (https:/ / creativecommons.org/licenses/by/ $4.0 /)$.

\begin{abstract}
In coastal areas, the tourism sector contributes to the local economy, generating income, employment, investments and tax revenues but the rapid urban expansion creates great pressure on local resources and infrastructures, with negative repercussions on the residents' quality of life, but also compromising the visitor's experience. These areas face problems such as the formation of meteorological effects known as heat islands, due to the soil sealing, and increased energy demand in the peak season. To evaluate the impact of urban growth spatial pattern and change, three strategic sustainable challenges_-urban form, urban energy, and urban outdoor comfort-were selected. The progress towards sustainability was measured and analyzed in a tourist city in the Algarve region, Portugal, for the period 2007-2018, using geographic information. A set of 2D and 3D indicators was derived for the building and block scales. Then, a change assessment based on cluster analysis was performed, and three different trends of sustainable development were identified and mapped. Results allow detecting the urban growth patterns that lead to more sustainable urban areas. The study revealed that a high sustainable development was observed in $12 \%$ of the changed blocks in the study area. All indicators suggest that the growth pattern of the coastal area is in line with the studied sustainability dimensions. However, most of the blocks that changed between 2007 and $2018(82 \%)$ followed a low sustainable development. These blocks had the lowest variation in the built volume and density, and consequently the lowest variations in the roof areas with good solar exposition. The urban development also privileged more detached and less compact buildings. This analysis will support the integration of 2D and 3D information into the planning process, assisting smart cities to comply with the sustainable development goals.
\end{abstract}

Keywords: 3D urban indicators; urban growth; sustainable development; urban form; solar potential; outdoor comfort

\section{Introduction}

The patterns of urban growth influence urban sustainability and different patterns of urban growth are expected to generate different impacts on the environment. Therefore, there is a need to understand the relationship between urban growth and the key sustainable development goals identified by cities during the planning process.

Recently, the concept of Smart Cities emerged as a strategy for reconsidering our perception of the built environment. According to [1] the concept of smart city is strictly linked to the idea of a digital city, due to the similarity of the two designations. Conceptually, smart cities represent a model of urban development, whose main function is based on the effort to capitalize on the new information and communication technologies (ICTs). The tendentious use of this statement makes one believe that any instrumental and technological innovation transforms a city into smart: this is a mistake [2]. The purpose of the Smart Cities also passes by ensuring prosperity, competitiveness, efficiency, and sustainability 
in various socio-economic levels. The Smart Cities agenda has gained real momentum in Europe [3,4], with the European Committee for Standardization and the European Committee for Electrotechnical Standardization proposing a more general definition on smart cities: "A Smart City is a city seeking to address sustainability issues via ICT-based solutions based on a multi-stakeholder, municipally based partnership".

The "smart" notion points to the idea of intelligent growth, involving better urban efficiency, by integrating conservation, economic development, and resources optimization while improving citizen's quality of life. The Big-Data era and the information-society life paradigm offers stakeholders and urban planners improved conditions for studying urban form and morphology. Thus, a diversity of both 2D and 3D spatial indicators have been introduced into research on urban sustainability, supporting smart strategies.

Sustainable development means development that balances the needs of current and future generations [5]. The study of urban sustainability is a multidisciplinary field of research and englobes many concepts such as compact city, eco-city, resilient city, 15-min city and sponge city. All these concepts seek ways for cities to meet the requirements of sustainability. Sustainability is most often defined in three dimensions. The social dimension is related to social fairness and equitable distribution of resources, the economic dimension is related to resource distribution and growth and the environmental dimension is related to protecting the environment and preserving natural ecosystems [5].

The rapid growth in cities and major agglomerations challenges sustainable urban development, with a range of environmental impacts like soil loss, flora or fauna and habitat fragmentation, and socio-economic impacts like heavy demand for new physical and social infrastructure provision, increased energy demand for domestic services, traffic congestion or poor sanitation conditions [6]. Spatial planning requires models and evaluation methods to describe urban form and existing conditions, as well as to provide alternative scenarios for the future development of the city [7]. According to [8], there are three main approaches to measure and analyze urban development towards sustainability-accounts, narrative assessments, and indicator-based assessments. The latter are generally organized around a set of indicators that deal with different topics necessary to portray urban growth. By using the same set of indicators over time, recent assessments can be compared with previous ones, making indicator-based assessments more useful for decision-making than other approaches.

\section{Literature Review}

Land Use and Land Cover (LULC) changes are the main challenges for sustainable urban development [9]. Therefore, local governments should have at their disposal tools to inform about the best strategies to mitigate the impact of urban morphology on the local climate. To be effective, such tools should consider horizontal and vertical growth of the built-up environment $[10,11]$. Earth Observation (EO) data provides an effective source of geographic information for calculating urban indicators, due to its ability to consistently obtain updated and detailed land cover information over large areas. For sustainability assessment, different EO-based indicators need to be applied to capture the distinct aspects of urban growth. The relevant literature has focused largely on the evolution of two-dimensional urban areas [12-15], using other variables like demography (e.g., population density) or other socio-economic factors (e.g., concentration, centrality, proximity) to study the intensification process. This is mainly due to the difficulty of obtaining elevation data in a fast, consistent, and replicable process. Nevertheless, urban growth boosts higher densification of populations and built environments. This relation results in vertical growth, typically through mid and high-rise buildings. 3D modeling can be used to assess the differences between surrounding heights of less compact areas, by showing where compactness may be occurring and to what vertical extent [16]. With the advent of new sensors (e.g., LiDAR — Light Detection and Ranging or SAR-Synthetic Aperture Radar) and image-processing algorithms, obtaining height information about the urban environment is nowadays a much more efficient process. Such data allows studying 
the spatial aspects of verticality and volume of the built environment. Consequently, more studies integrating 3D information in the spatial and temporal analysis of the urban environment, are now available in the literature [12-17].

Nevertheless, to aid sustainable urban planning, there is a need for new methods, spatial metrics, scenario-based models and tools for integrating and measuring in the three spatial dimensions [16,18-22].

There are many indicators to assess sustainable development, that deal with distinct aspects of cities like population, housing, economy, transportation, land use, energy, etc. [23]. In this work, we selected three strategic sustainable challenges to measure and assess urban growth towards sustainability at the local scale based on spatial analysis: urban morphology and form, solar energy, and outdoor comfort. All three selected strategic sustainable challenges are transversal to the three sustainable dimensions. Urban form is not only related to many environmental impacts but also with economic development and wellbeing. Urban form influences the land use, the provision of open spaces, the commuting movements, the air quality, the noise pollution, or the urban heat island effect. By providing building densities capable of minimizing the number and lengths of trips by modes of transport also impacts the level of greenhouse gas emissions. However, urban form also influences economic aspects, by impacting the energy consumption (for heating, cooling, lighting, cooking) and the suitability for installing solar-based systems, both with direct impact on the environmental quality of the urban area. Furthermore, the urban form can promote the quality of life, including social interactions and ready access to services and facilities. Urban solar energy is directly linked with economics and environmental dimensions since renewable sources of energy are cleaner modes of power generation that can also diminish the local dependency on fuel fossils. Furthermore, promoting urban solar sustainability enables self-consumption, which also contributes to raising awareness and behavior change, with citizens seeing themselves as a part of the solution for achieving clean and healthy cities. Comfortable public spaces, easily walkable, promote social well-being and a high-quality urban environment.

\subsection{Urban Form}

Urban morphology expresses the different aspects of urban form and the physical density of built environments [24]. Urban morphology indicators are useful to understand urban form dynamics, i.e., the spatial structure and patterns of the built environment. Many studies show that the urban structure impacts significantly the local environment, by promoting Urban Heat Island (UHI) effect [25,26], causing high wind speeds [27,28], affecting the air quality and noise pollution due to traffic congestion [29,30]. Urban morphology is also related to energy demand by impacting the buildings' electrical demand for heating, cooling and artificial lighting [31-33]. Urban morphology indicators include ratios of surfaces, volumes or lengths like building aspect ratio, floor space index, building density, porosity, compacity, among others.

Rode et al. [31] studied the relationship between urban form and residential heatenergy demand at built forms in London, Paris, Berlin and Istanbul, using five measures of urban morphology: building height, the surface coverage of buildings, open space ratio, and building density surface-to-volume ratio. The building density and building height average were classified as good measures of heat-energy efficiency, both correlating negatively with the heat-energy demand. They concluded that tall and compact buildings had the highest heat-energy efficiency at the neighborhood scale, while detached housing had the lowest. Mahtta et al. [12] characterized urban form in 2D and 3D and proposed a worldwide dataset of urban volumetric growth. First, urban growth trends were estimated for both regions and countries; second, a pixel-based analysis was performed to determine how urban growth patterns cluster. Finally, the variations of these clusters across cities and geographies were analyzed. Shirowzhan et al. [14] proposed a set of 3D metrics for assessing spatial and temporal sustainable urban form-the ratio of volume change, 3D mass index and 3D space index - and used them to assess building and vegetation change 
detection. The change detection method was based on an integrated approach of support vector machine together with digital surface model (DSM) differencing. Zhao et al. [15] demonstrated the utility of LiDAR data to characterize 3D morphology and understand its dynamics for 24 years. In this study, the urban development was characterized in each period using nine urban morphological types (based on building surface fraction, pervious surface fraction and height of constructed elements). The urban expansion was then assessed in terms of intensification, sprawling expansion, and efficient expansion. Results were compared with local plans to assess its conformance with the 'compact and efficient growth' policies.

\subsection{Urban Solar Energy}

Energy use is globally recognized as a key issue for urban sustainable development [5,34]. Promoting the use of renewable sources of energy in the residential sector is a way of reducing greenhouse gas emissions associated with fossil fuels usage while decentralizing the electricity sector and promoting the local generation of clean power (especially important in remote areas) [35]. Consequently, reducing the energy consumption of urban buildings and improving the use of solar energy has become the focus of many countries [36]. The urban insertion of renewable energy production depends on the adoption of public policies, municipal incentives, and the local solar conditions [37,38]. The roof of buildings in the city can be used to install solar thermal collectors or photovoltaic (PV) power generation systems, which is considered the fastest growing technology and the main use of solar energy in urban buildings (e.g., for cooling, heating, hot water supply, lighting, and kitchen appliances) [36,39]. In this context, urban morphology has a direct impact on energy consumption at the building level. Factors such as the roof's slope, area, orientation, and shaded area are determinants for the success of solar energy generation systems. Understanding the impact of these factors on energy consumption (i.e., quantifying local capabilities) is crucial to determine where in the city is the largest potential to reduce energy consumption, and which areas are more suitable and should be prioritized for the development of energy efficiency policies in line with the sustainable development goals [37].

Solar availability in the urban environment is a common spatial indicator to assess the potential use of renewable energies. The impact of building and block morphology on solar access and harnessing has already been explored in different studies. Martins et al. [40] found that the street canyon aspect ratio, the spacing between buildings, and surface equivalent albedo are the most significant design factors affecting solar potential. Santos et al. [37] assessed the photovoltaic potential of residential buildings and compared it with the local electricity demand. The results showed that $25 \%$ of the local electricity demand in residential buildings can be met with the installation of photovoltaic (PV) systems on the rooftops. Chatzipoulka et al. [41] demonstrated that urban density has a negative impact on solar potential. Supported by the morphological and solar analysis of London's 24 representative urban forms, they concluded that average spacing between buildings, site coverage, directionality and complexity of building form, and variance in building height, all are key factors that affect solar potential on the open space and building facades. Mohajeri et al. [42] studied the relation between urban compactness indicators and solar energy potential and found that of the six indicators, the volume-area ratio showed the best correlation with the annual solar irradiation. Sarralde et al. [43] tested several urban morphology descriptors-such as the average building perimeter, the variation in building heights, the average spacing between buildings - to predict solar irradiance of roofs and facades. They found that according to the neighborhood scenario, the optimum combinations of variables of urban form could increase solar radiation of roofs and facades by 9 and $45 \%$, suggesting that prioritization might be needed considering the potential conflict between the parameters. Zhang et al. [44] simulated the effect of building topology on solar potential and energy used and found that rooftop photovoltaic for courtyard typology reduced building energy use intensity by up to $25 \%$. 


\subsection{Urban Outdoor Comfort}

Outdoor thermal comfort is a key aspect of sustainable urban design [45,46]. The outdoor comfort and public space quality for pedestrian use depend on several factors like microclimate (e.g., air ventilation, mean air temperature or relative humidity), presence of water elements and green infrastructures, pavement materials, and urban morphology. The urban layout has a direct impact on microclimate parameters such as air temperature, humidity, radiant temperature, or ventilation. Furthermore, it can also aggravate the occlusion and reflection between buildings, which not only affects the distribution and absorption of solar radiation in buildings but also further affects the thermal environment and the public space quality for pedestrians [36,47].

Alavipanah et al. [10] studied the effect of multi-dimensional indicators, like building volume, shadow footprint and building height to width, on land surface temperature. The results showed that the $3 \mathrm{D}$ indicators are more determinant than $2 \mathrm{D}$ ones in modeling the surface temperature at distinct urban forms of the study area. While a higher exposure to the sky can be beneficial to daylight access for urban open spaces and building interior, the increased sky exposure may also lead to excessive solar radiation on the urban surface. This high insolation has a direct impact on building energy consumption for cooling and ventilation. Thermal comfort for people can also be compromised if no shadowing is provided. Therefore, sky exposure is a significant parameter when studying outdoor thermal comfort. The Sky View Factor (SVF) - the proportion of sky visible from a point to the overall sky dome- - has been used to evaluate the relation between morphology, sunlight access/shadowing and air temperature [22,24,48-52]. SVF has a dimensionless value between 0 and 1 representing a completely obscured and unobscured sky, respectively [48]. Yang et al. [51] applied a 3D urban surface energy balance model to assess the relevance of urban geometry on urban albedo and street surface temperature. Results showed that the average street surface temperature of a high-rise high-density city (i.e., with a smaller SVF) is lower than a low-rise low-density city. Ahmadi et al. [53] studied the role of SVF in human thermal comfort using microclimate simulation. Several street scenarios were studied and impacts in thermal comfort were evaluated through human-bio meteorological indexes. Results showed that SVF higher than 0.6 leads to higher heat stress.

From the literature review, we conclude that the impact of urban morphology on the sustainability of the urban form, solar energy or outdoor comfort is a topic of increasing research interest. However, to the best of our knowledge, the implications of 3D urban growth in the urban form, the solar access, or the outdoor comfort dynamics, have not yet been investigated from a sustainable development point of view. The main goal of this work is to present a straightforward methodology, based on the 3D model of an urban area in two periods, to evaluate if urban growth is following a sustainable development trend or if it is moving away from it. For that, we propose a methodology to (1) measure the 2D and $3 \mathrm{D}$ urban growth, (2) identify typologies of urban growth pattern, based on three strategic sustainable challenges - urban sustainable form, urban solar energy, and outdoor comfort, at the local scale-and, (3) assess progress towards urban sustainable development. A secondary goal was to select indicators that are easy to apply, easy to calculate, relevant to local levels, and contribute to the achievement of the sustainable development targets, based on already existing 2D and 3D municipal data. Such knowledge about the urban growth process constitutes a piece of valuable information to assist cities moving towards sustainability and resilience, the ultimate goals of the smart city movement.

The paper is organized as follows: in Section 3 we present the study area (Section 3.1), the selected materials (Section 3.2) and the three-step methodological approach (Section 3.3). Section 4 discusses the results in terms of urban growth typologies (Section 4.1) and the multiple implications for urban sustainability planning (Section 4.2). Finally, Section 5 summarizes the main findings and highlights the potential advantages and limitations of the proposed methodology. 


\section{Materials and Methods}

\subsection{Study Area}

The Algarve region is a popular sea and sun tourist destination, and the population increases $43 \%$ in the summer period due to the tourist influx [54]. Coastal urban tourist areas face two types of problems. On the one hand, being urban areas with a large part of their soil sealed makes them vulnerable to meteorological effects such as heat islands. On the other hand, because they are in coastal areas, they suffer from increased problems in their management given the strong tourist pressure they are subject to. In fact, in cities with high tourist activity, urban pressures on the territory are increased, overloading local infrastructures, with negative repercussions on the residents' quality of life, but also compromising the visitor's experience. These effects are most felt in seasonal tourist areas, such as beach destinations, where the mass concentration of tourist flows, in time and space, leads to increased energy demand and other environmental impacts.

Nowadays, one of the main challenges that the local government faces is to ensure the sustainability of urban growth and development. The tourism sector has also shown to be alert to issues related to sustainability and energy efficiency [54] not only about boosting its business model but also regarding the image it wants to transmit to its main consumers.

To study the urban growth, the main urban zone of Portimão City, in the Algarve region, was selected (Figure 1). Portimão has a hot-summer Mediterranean climate (Köppen: Csa), characterized by hot dry summers and mild wet winters, moderated by the Atlantic Ocean proximity, making it a popular sun, sea and beach destination. Therefore, the socio-economic structure of Portimão is heavily reliant on tourism. Since the 1970s, the area has been subjected to intense urbanization, starting in the surroundings of Praia da Rocha, with the construction of large hotel units and second homes, followed by other tourist projects [55]. The continuous tourist pressure contributed to the substantial urban development felt in recent years, with many new constructions occurring outside the urban expansion zones $[56,57]$. While this zone occupies a small part of the municipality-12.6 km² (out of $182 \mathrm{~km}^{2}$ ) - it is the home to 40,679 inhabitants (census data from 2011), which represents $73 \%$ of the total population of the municipality.

\subsection{Earth Observation and Ancillary Data}

This research used a range of multi-resolution 2D and 3D geographic data, all based on the national coordinate system ETRS89/Portugal TM06. The 2D dataset included building footprints, orthophoto maps and census urban blocks:

- To represent the buildings within the urban context, a vector file with footprints was used. The most recent file is from 2018 and is part of the municipal cartography. However, the footprints from 2007 were not available and had to be obtained by visual interpretation of a very-high resolution orthophoto $(50 \mathrm{~cm})$ from 2007 . The 2007 footprints were then produced by removing 2018 buildings that did not appear in the 2007 image.

- The census blocks were obtained from the National Statistical Institute of Portugal (INE) that conducts the decadal censuses of the population. The information is produced in small statistical areas-statistical sections and subsections-defined by polygons in a Geographic Information System. From this base, we selected the subsections that represent the smallest homogeneous areas, corresponding to a block in urban areas. The total number of urban blocks in the study area was 680 .

- The 3D dataset included a digital surface model (DSM) and a digital terrain model (DTM):

A DSM with a $2 \mathrm{~m}$ resolution, representing the elevation on the study area in 2018 was obtained by applying a matching method — the MATCH-T DSM [58]—on aerial image stereo pairs. The DSM has a maximum z error of $86 \mathrm{~cm}$. 
A DTM with a $1 \mathrm{~m}$ resolution, representing the terrain in 2007 was obtained from the municipal cartography. This is the most updated information available for the study area. The DTM was resampled for the DSM resolution for proper data comparison.

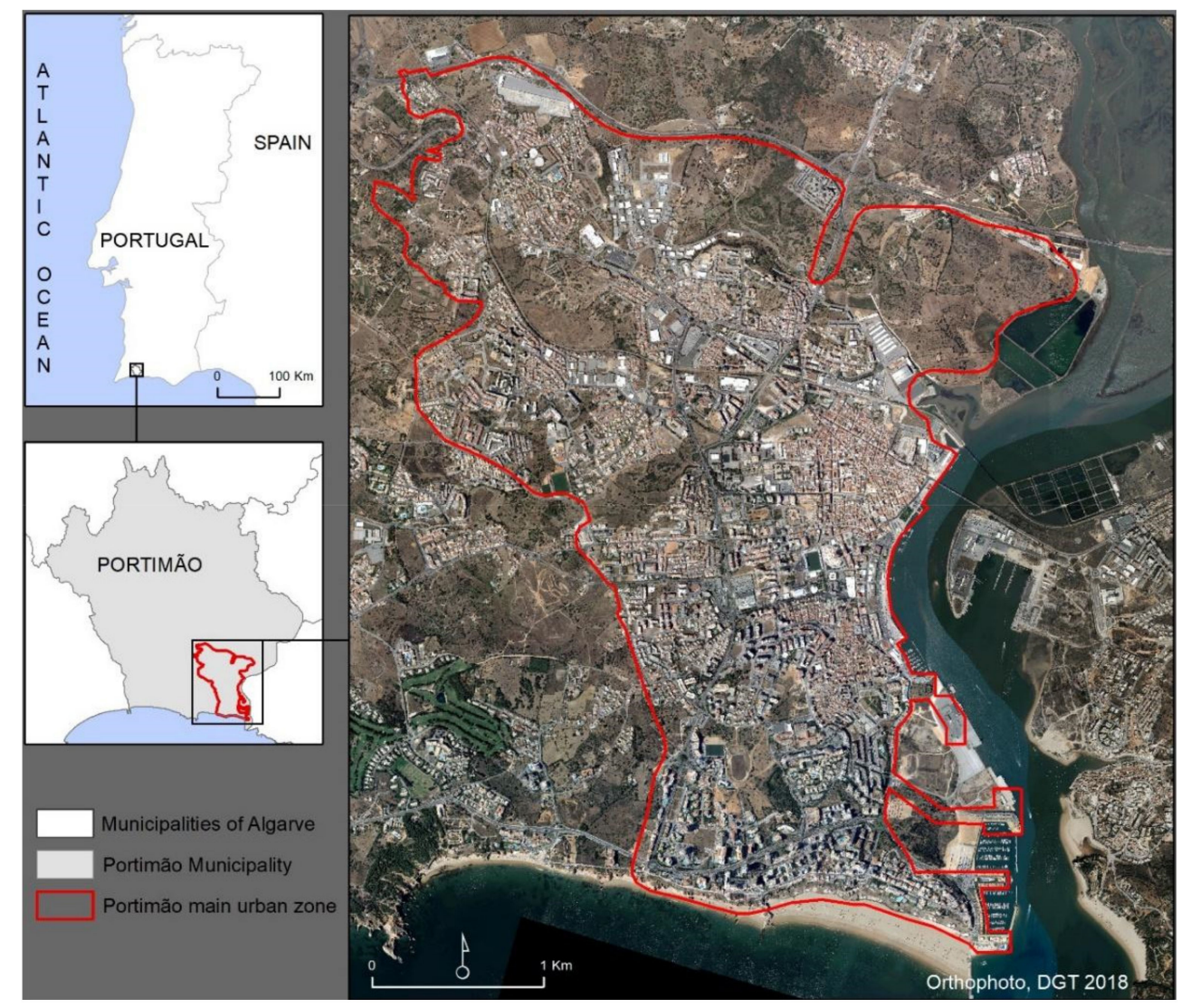

Figure 1. Study area located in Algarve Region, Portugal.

\subsection{Methods}

The methodology follows a 3-step approach. It starts with data preparation for assessing the built height and volume for each period (Section 3.3.1). Then, 2D and 3D Indicators for Urban Sustainability Analysis are produced for the individual building and the block scale for each period (Section 3.3.2). In the next step, a change assessment is applied to select blocks with new and/or demolished buildings and cluster analysis of the changed blocks is performed. The results will provide a spatial and temporal pattern of horizontal and vertical sustainable urban growth (Section 3.3.3).

\subsubsection{Data Preparation}

In this research, spatial and temporal changes of 2D and 3D patterns of urban sustainable development are explored at the individual building and the block scale. Both scales require distinct information.

For the building scale, the height and volume for 2007 and 2018 are the two geometric attributes required. That information was obtained using the 2D and 3D datasets. First, through the subtraction of the $\mathrm{DTM}_{2007}$ to the $\mathrm{DSM}_{2018}$, a normalized DSM (nDSM) was produced. The nDSM identifies all objects that lie above the terrain such as buildings, bridges, and trees. Then, buildings' height and volume were calculated by overlaying the building footprints and the nDSM (Figure 2).

For the block scale, besides the built height and volume, temporal information about the surface (i.e., the DSM) is also required. In the 3D dataset, however, this information is only available for 2018 , so, to study the spatial and temporal changes, information about the surface in the first period of analysis (2007) is required. The $\mathrm{DSM}_{2007}$ was produced 
through map algebra (conditional evaluation) using the $\mathrm{DSM}_{2018}$, the $\mathrm{DTM}_{2007}$ and the building footprints for both dates. The condition was implemented using the following expression:

$$
\text { IF Building } 2007<>\text { Building }_{2018} \text { THEN DTM } 2007 \text { ELSE DSM } 2018 \text {, }
$$

Meaning that if the cell is evaluated as true, i.e., if it is not a building in 2018, it will receive the value of the $\mathrm{DTM}_{2007}$. If the cell is evaluated as false, it will receive the value of the $\mathrm{DSM}_{2018}$. Using this method, all cells in the study area attributed an elevation value, based on the cell's value in the building files and the conditional statement. The final raster file represents the $\mathrm{DSM}_{2007}$ of the study area.

At the end of this pre-processing stage, the following information is available: the building height, the building volume, and the DSM, for both 2007 and 2018 years.

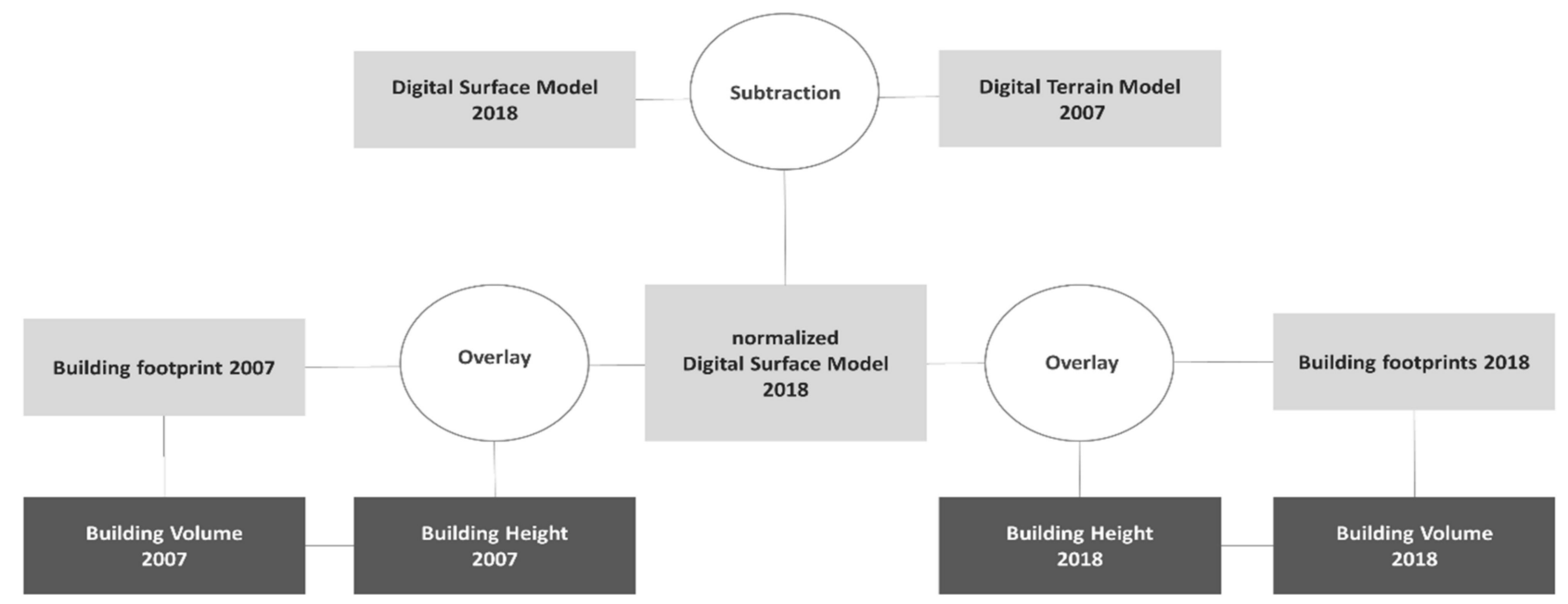

Figure 2. Methodology to obtain relative heights and volumes from 2D (building footprints) and 3D datasets (DSM and DTM).

\subsubsection{Spatial Indicators for Urban Sustainability Analysis}

Two geographical scales were adopted for the analysis of urban development: the building and the urban block scale. Following the methodological framework in Figure 3 and using the information available in the $2 \mathrm{D}$ and $3 \mathrm{D}$ datasets, several indicators were computed for each building in the study area. Then, and to characterize the urban development on the urban block scale, three groups of sustainability indicators considering the urban form, solar potential and outdoor comfort were used. These groups of indicators are described in the next sections.

Building Indicators

The individual geometric and volumetric attributes of every building in the study area were retrieved from the building footprints and the nDSM. Using those attributes, a set of eight indicators was proposed (Table 1):

- $\quad$ Building Length (L), Width (W), Area (A), Height (H) and Volume (V)—-these primary attributes are obtained in the building footprint (i.e., the polygon length, width and area) and the nDSM (the height value). The volume is then the product of the area and the height of each building identified in the building footprint.

- Building Aspect Ratio (BAR) - this index measures the shape of the buildings by comparing the length (the longer dimension) and width (the shorter dimension). It defines the surface area by which heat is transferred between the interior and the outdoor environment, so it has a big impact on energy efficiency [59]. The higher the 
BAR, the higher is the exposed surface area, which increases the energy transfer, and thus urban sustainability.

- 3D Mass Index-is the ratio of the volume of buildings to the total volume of an assumed cube in the block. The cube's footprint is the ground surface area comprising all buildings, and its height matches the tallest building height in the study area. It is a measure of 3D urban form compactness. Compact urban form is identified by the Intergovernmental Panel on Climate Change (IPCC) as an important sectoral climate mitigation measure [60], attributed to lower per capita energy use [61].

- Contiguity - is the ratio of the facade area (i.e., the vertical envelope) next to other buildings to the facade area exposed to the outdoor space. Null contiguity stands for detached buildings, while buildings with common boundaries will have higher values. The level of adjacencies between buildings impacts the level of heat transmission (since party walls do not transmit heat to the outside space). Fewer contact areas mean lower contiguity and higher heat exchanges with the outdoor.

- Rooftop Solar Potential-quantifies the suitable roof area to receive photovoltaic panels. The first step is to model the solar radiation at the surface considering the worst energy scenario-the winter solstice. The solar mapping is performed using Solar Analysis from ArcGIS [62], following the methodology proposed by [37]. The solar map provides radiation values, calculated in Watt-Hours $/$ meter $^{2}$. The radiation values are then classified into quartiles. Through an overlay operation, the solar radiation at every building footprint is assessed and only those roof areas that are within the fourth quartile of solar energy are considered suitable for solar panel installation.

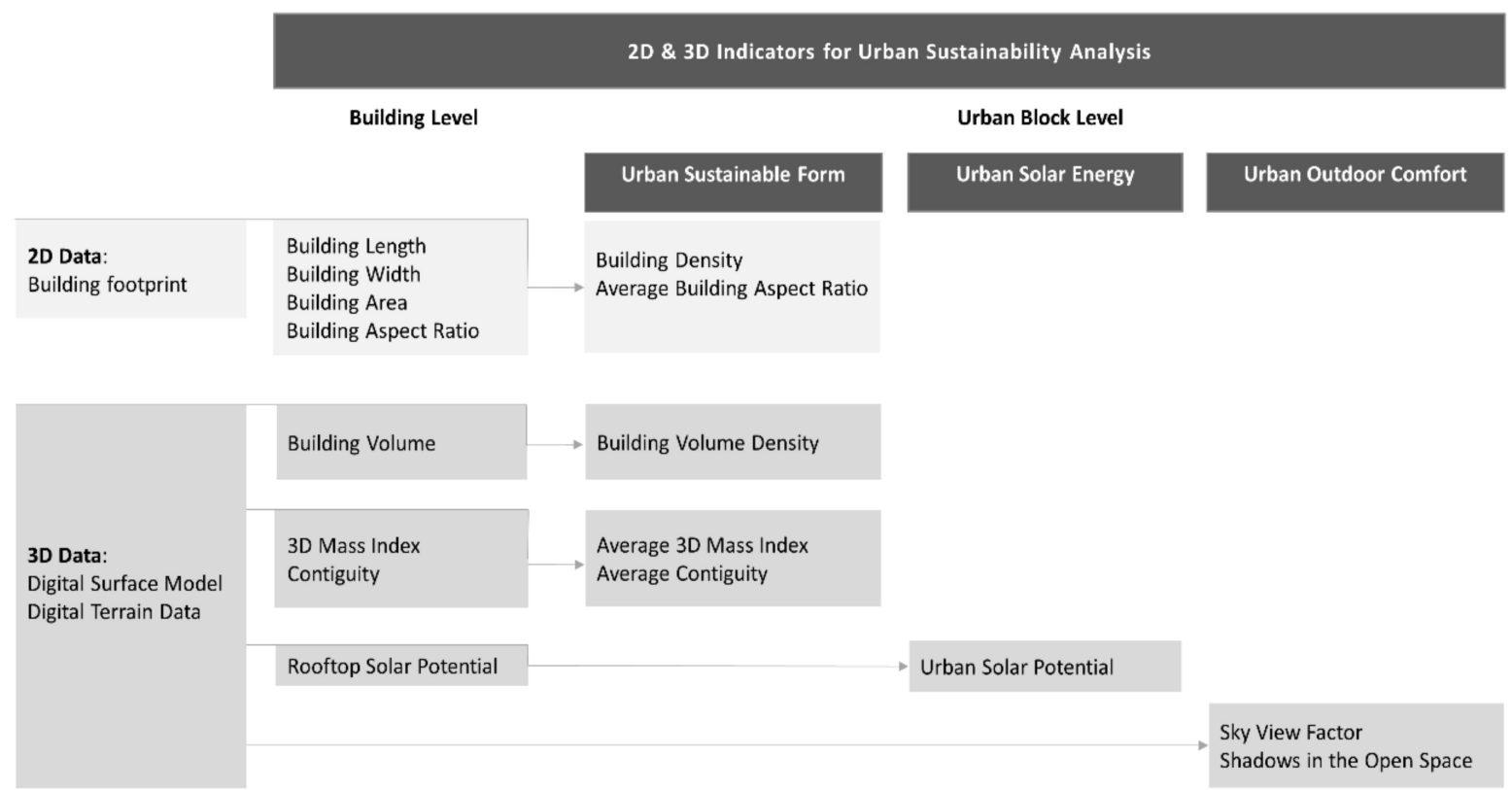

Figure 3. Proposed 2D and 3D indicators for urban sustainability analysis at the building and the urban block scale.

\section{Urban Sustainable Form Indicators}

To study the urban form, all individual building data were aggregated to the Portuguese Georeferenced Information Base (BGRI), the national GIS census database produced by the INE. This referencing system divides the parish areas into smaller statistical territorial units. For this study, we selected the smallest territorial unit-the subsection statistical section-that corresponds to the block in urban areas. At the urban block scale, the following seven indicators were proposed (Table 2):

- Building Density (BD) - the indicator accounts for the number of buildings per unit of area. This information is pertinent in urban planning for it shows a city's evolution, based on the quantification of new and demolished buildings within the urban area. 
- Built Volume Density (BVD)—is calculated by summing the built-up volume aggregated by block area. This index shows which typologies are privileged: single-family (low BVD) or multi-family houses (higher BVD). Densification is one of the core design strategies of the compact city for achieving the goals of sustainability [43,44]. It enables, through the concentration of human activities, efficient use of resources such as land and energy, while preserving large greenfield areas in its surroundings. Consequently, a sustainable development trend shall prioritize higher built volume densities.

- Based on individual building aggregation, the following indicators are calculated for the block scale: Average Building Aspect Ratio (AvBAR), Average 3D Mass Index (Av3DMI) and Average Contiguity (AvCt).

Table 1. 2D and 3D indicators for individual buildings and their formulas.

\begin{tabular}{|c|c|c|c|}
\hline Indicators & $\begin{array}{l}\text { Scale of } \\
\text { Analysis }\end{array}$ & Dimension & Formula \\
\hline Building Length $(L)$ & Building & $2 \mathrm{D}$ & $L$ is the longest side of the building \\
\hline Building Width $(W)$ & Building & $2 \mathrm{D}$ & $W$ is the shorter side of the building \\
\hline Building Area $(A)$ & Building & $2 \mathrm{D}$ & $A=L \times W$ \\
\hline Building Aspect Ratio (BAR) & Building & $2 \mathrm{D}$ & $B A R=\frac{L}{W}$ \\
\hline Building Volume $(V)$ & Building & $3 \mathrm{D}$ & $\begin{array}{l}\qquad V=\sum_{i=1}^{p} h_{i} \times n D S M_{\text {resolution }} \\
h_{i} \text { is the height value, obtained from the nDSM, of each } \\
\text { pixel included in the building footprint }\end{array}$ \\
\hline 3D Mass Index (3DMI) & Building & $3 \mathrm{D}$ & $\begin{array}{l}3 D M I=\frac{V}{\max \left\{h_{i}\right\} \times A} \\
h_{i} \text { is the height of each pixel included on the building } \\
\text { footprint }\end{array}$ \\
\hline Contiguity $(C t)$ & Building & $3 \mathrm{D}$ & $\begin{array}{c}C t=\frac{\text { Adjacent Facade Area }}{\text { Exposed Facade Area }} \\
R S P=A Q 4_{\text {solarmap }}\end{array}$ \\
\hline Rooftop Solar Potential (RSP) & Building & $3 \mathrm{D}$ & $\begin{array}{l}A Q 4_{\text {Solarmap }} \text { is the area of pixels from the building } \\
\text { footprint that are classified in the } 4 \text { th Quartile of the } \\
\text { winter solar map }\end{array}$ \\
\hline
\end{tabular}

Table 2. Urban sustainable form indicators and their formulas at the block scale.

\begin{tabular}{|c|c|c|c|}
\hline Indicators & $\begin{array}{l}\text { Scale of } \\
\text { Analysis }\end{array}$ & Dimension & Formula \\
\hline Building Density $(B D)$ & Block & $2 \mathrm{D}$ & $\begin{array}{c}B D=\frac{\sum_{i=1}^{N} B_{i}}{A_{\text {Block }}} \\
B_{i} \text { are the buildings on the block } \\
A_{\text {Block }} \text { is the area of the block }\end{array}$ \\
\hline $\begin{array}{l}\text { Average Building Aspect } \\
\text { Ratio }(A v B A R)\end{array}$ & Block & $2 \mathrm{D}$ & $\begin{array}{c}A v B A R=\frac{\sum_{i=1}^{N} B A R_{i}}{N} \\
B A R_{i} \text { is the } B A R \text { of each building on the block } \\
N \text { is the total number of buildings on the block }\end{array}$ \\
\hline Built Volume Density (BVD) & Block & $3 \mathrm{D}$ & $\begin{array}{c}B V D=\frac{\sum_{i=1}^{N} V_{i}}{A_{B l o c k}} \\
V_{i} \text { is the volume of each building on the block } \\
A_{\text {Block }} \text { is the area of the block }\end{array}$ \\
\hline $\begin{array}{l}\text { Average 3D Mass Index } \\
\text { (Av3DMI) }\end{array}$ & Block & $3 \mathrm{D}$ & $\begin{array}{l}A v 3 D M I=\frac{\sum_{i=1}^{N} 3 D M I_{i}}{N} \\
3 D M I_{i} \text { is the } 3 D M I \text { of each building on the block } \\
N \text { is the total number of buildings on the block }\end{array}$ \\
\hline Average Contiguity $(A v C t)$ & Block & $3 \mathrm{D}$ & $\begin{array}{c}A v C t=\frac{\sum_{i=1}^{N} C t_{i}}{N} \\
C t_{i} \text { is the 3DMI of each building on the block } \\
N \text { is the total number of buildings on the block }\end{array}$ \\
\hline
\end{tabular}


Urban Solar Energy Indicator

To characterize the built environment potential to receive solar panels, the information regarding the average potential of each rooftop within the block, as described in Section 3.3.2 (in Table 1) is proposed (Table 3).

Table 3. Urban solar indicator and its formula.

\begin{tabular}{cccc}
\hline Indicators & $\begin{array}{c}\text { Scale of } \\
\text { Analysis }\end{array}$ & Dimension & Formula \\
\hline $\begin{array}{c}\text { Urban Solar } \\
\text { Potential (USP) }\end{array}$ & Block & $3 \mathrm{D}$ & $\begin{array}{c}U S P=\frac{\sum_{i=1}^{N} R S P_{i}}{\sum_{i=1}^{N} A_{i}} \\
R S P_{i} \text { is the } R S P \text { of each building on the block } \\
A_{i} \text { is the area of each building on the block }\end{array}$ \\
\hline
\end{tabular}

\section{Urban Outdoor Comfort Indicators}

One of the best ways to improve sustainable and soft mobility in cities is to create attractive and pleasant places that provide comfortable walking and cycling environment. The urban morphology can have a great impact on outdoor comfort, favoring daylight access and shadows during summer. To measure these two conditions, the Sky View Factor and the shadows intensity in the open space were proposed (Table 4):

- Sky View Factor-this indicator defines the ratio of sky hemisphere visible from the ground, and that is not obstructed by buildings, terrain, or trees. SVF is a common indicator used in climate-related studies since it directly impacts the long-wave radiation flux emitted by built structures to the sky during the night period. When the entire sky is blocked from view by obstacles, SVF equals 0 . For lower values of SVF, the amount of heat released during daytime is limited, increasing net heat storage within the buildings, and thus increasing UHI. Higher SVF values account for greater sky visibility, and therefore, heated air during the daytime is less trapped among the buildings and is more effectively emitted to the atmosphere [63]. Therefore, a more desirable street configuration in terms of comfortable thermal environments is characterized by high SVF values [64].

- In this study, SVF was calculated in QGIS software plug-in SAGA-GIS [65] and uses the DSM to describe the buildings and terrain elevation in each pixel. The remaining parameters include the number of sectors (8) and the distance of search $(10,000)$.

- Shadows in the open space-this indicator quantifies the area of open space that is shaded. In hot-summer Mediterranean climates, pedestrian comfort is highly affected by the amount of shaded area. In these regions, climate-responsive urban design can play an important role in cooling down the built environment [66], making it more pleasant for walking and cycling activities.

The procedure to obtain the shadow area in the open space is like the roof solar potential assessment and begins with the model of the solar radiation at the surface. However, it differs in two aspects: (1) the selected season is the hottest scenario-the summer solstice (since the study area is a summer tourist area)-and (2) for shadow mapping, the first quartile of solar energy is used. The result is the map of shadows on the whole surface during the summer. Through an overlay analysis, the built area is removed and the map of the shadows in the open space is obtained. 
Table 4. Urban outdoor comfort indicators and their formulas.

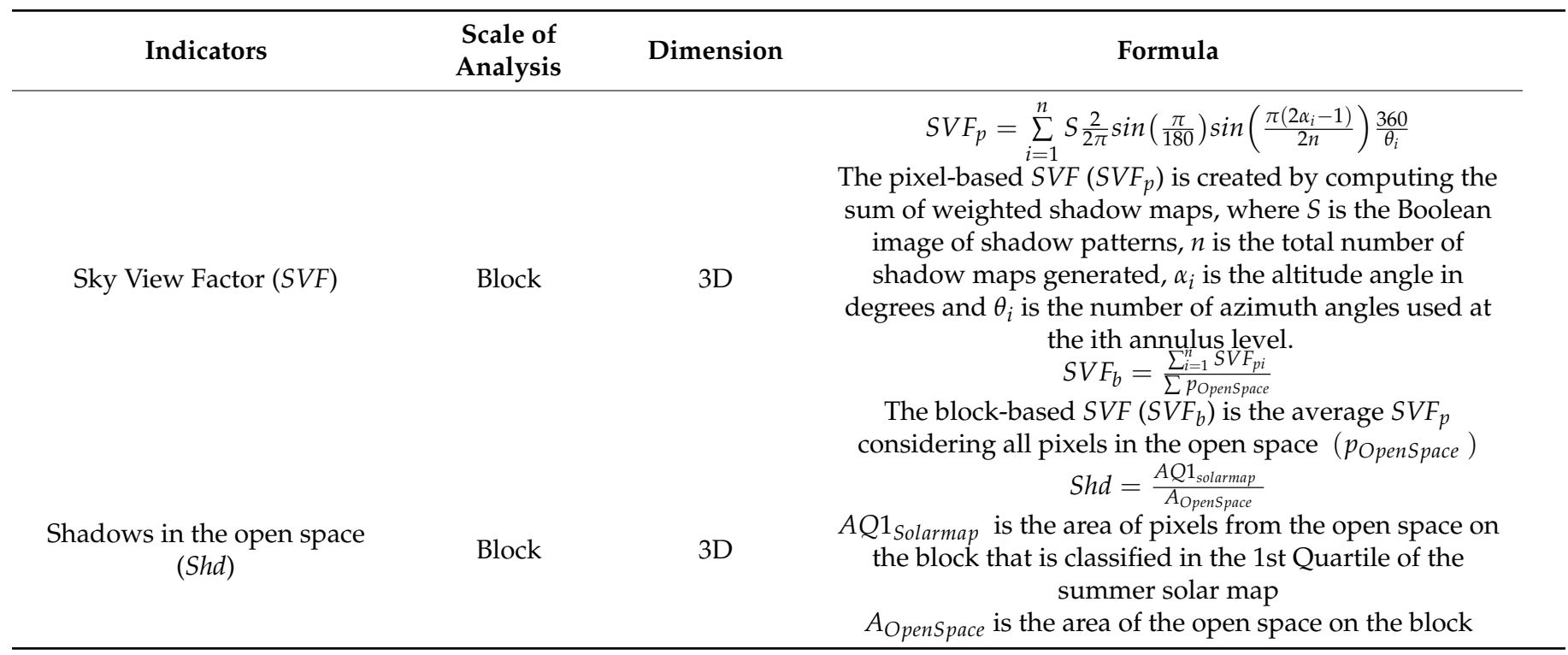

\subsubsection{Change Assessment and Cluster Analysis}

Change detection was applied after assessing the indicators for the block scale for 2007 and 2018 (Figure 4). In the first step, change blocks were identified based on both the Building Density and the Built Volume Density indicators. These indicators account for changes in new and demolished buildings, in number and volume. Then, the eight urban indicators for sustainability analysis (Table 2, Table 3, Table 4) from 2007 were subtracted from those from 2018. The result is a set of eight variables calculated for each block that characterizes the urban development of the study area.

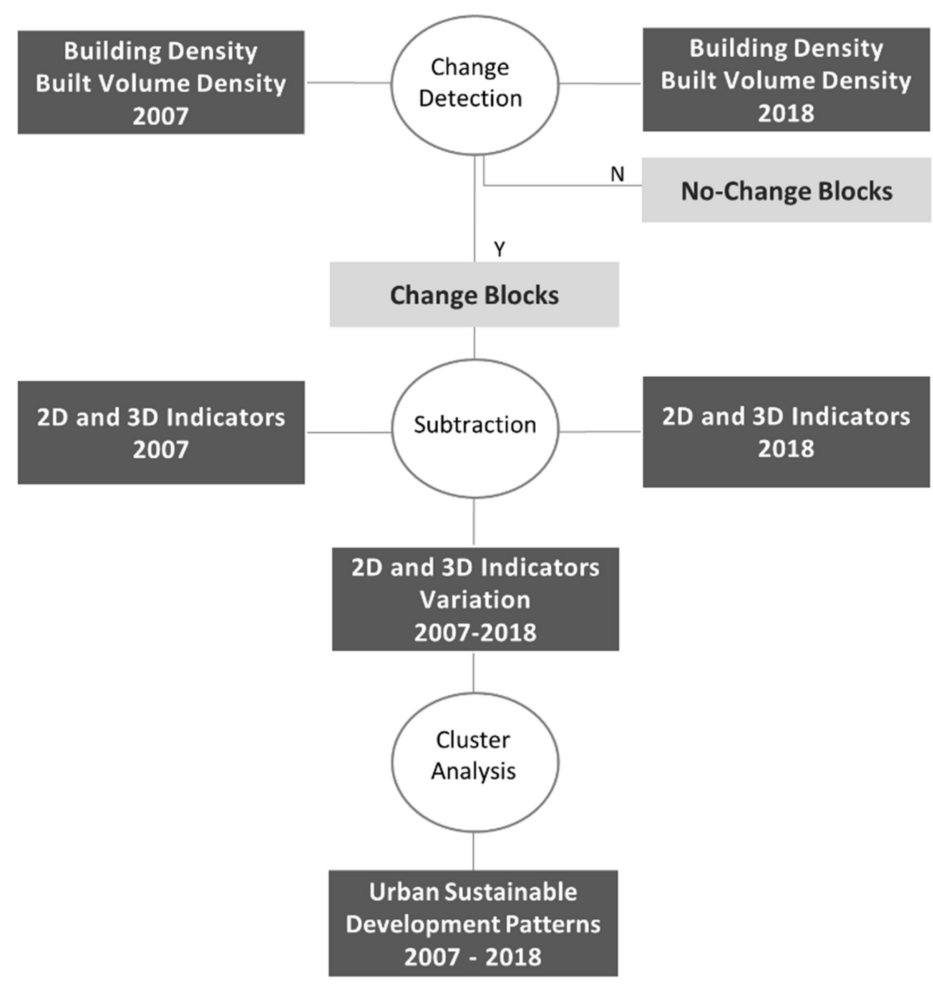

Figure 4. Methodology for assessing urban sustainable development patterns at the block scale in the period 2007-2018. 
The variation of the urban indicators for each block was then investigated through cluster analysis. The optimal number of clusters was determined through the CalinskiHarabasz pseudo F-statistic (implemented in the group analysis tool within ArcGIS, ESRI). This statistic shows how many groups will be most effective at distinguishing the features and variables specified.

Given the number of clusters to create, and the variations of the urban indicators for each block, the clustering algorithm will look both for a solution where all the indicators within each cluster are as similar as possible, and all the clusters themselves are as different as possible. For this step, no spatial constraints shall be specified so as not to force similar urban growth clusters to be spatially proximal. The variables were standardized before clustering analysis. Standardization involved a z-transformation, where the mean for all values is subtracted from each value and divided by the standard deviation for all values. Standardization puts all the attributes on the same scale (from 0 to 1.0). The K-Means algorithm was used for grouping similar blocks. For each cluster of blocks, a mean data center was computed, and each block was reassigned to the closest center. Computing a mean data center for each cluster and then reassigning the block to the closest center continued until group membership stabilizes (up to a maximum number of 100 iterations). The Euclidean distance method was used to calculate the distance from each block to neighboring blocks.

After analyzing the statistical distributions of each cluster in the eight urban indicators, a typology of urban growth at the block scale was proposed and used to characterize the sustainable patterns in the study area. In this work, the sustainable development trend was assessed following the three selected strategic sustainable challenges: urban sustainable form, solar energy, and outdoor comfort. Higher densities and compact urban form are perceived as more sustainable than other urban patterns [67-69]. Based on the proposed indicators of urban form (Table 2), a high level of sustainable urban form corresponds to high built volume densities, increased exposed surface area (high values of BAR), high compactness (high values of 3D Mass Index), and greater contiguity. For the urban solar sustainable analysis, rooftop areas with high irradiance (i.e., solar potential) are more suitable than rooftops with low irradiance. For the outdoor comfort, the presence of shadowed areas in the open space and the amount of visible sky (low SVF) are good indicators of public space quality and contribute to the city sustainable development.

\section{Results and Discussion}

The described procedure in Section 3 was applied to the study area. The main results are presented herein.

\subsection{Measure 2D and 3D Urban Growth}

From the building footprints available for the urban area of Portimão, we verified that 10,271 buildings already existed in 2007 and that number increased to 10754, in 2018, meaning that 484 new constructions were built in this period (a variation of $5 \%$ ). Following the methodological framework presented in Figure 3, eight indicators-Building Length (L), Width (W), Area (A), Height (H) and Volume (V), Building Aspect Ratio (BAR), 3D Mass Index, Contiguity and Rooftop Solar Potential-were computed for every building in the study area in both periods of analysis (i.e., 21,025 buildings). Looking at these results, we conclude that the top 10 tallest buildings in the study area (i.e., with more than $75 \mathrm{~m}$ in height, approximately 25 floors) are the same in both periods, but when looking into the top 10 most volumetric ones, we see that there are now three new buildings in the three first positions of the rank, that were built between 2007 and 2018.

Regarding building function, the residential sector was responsible for $84 \%$ of the new constructions, followed by services and commerce (16\%), and tourist developments (1\%).

In Portugal, the Thermal Performance Building Regulations [70] determines that new homes (or buildings with significant remodeling works) should include a solar thermal collector $\left(1 \mathrm{~m}^{2}\right.$ per resident). In the study area only the more recent new constructions 
comply with these regulations. The information is not easily accessible, but through a visual inspection of the very-high resolution orthophotos available, we could assess that $52 \%$ of the new buildings have solar panels. With the development of a Roadmap for Carbon Neutrality in 2050, the Portuguese government aims to incentivize the installation of solar systems so that by 2050 solar power represents $50 \%$ of the total installed capacity in the electrical system. Therefore, the adoption of solar systems is expected to rise in the following years, namely in the Algarve region, where solar irradiance is high.

Through the analysis of the growth of new buildings according to the distance from the coastline (Figure 5, Table 5), we verified that, within the first $500 \mathrm{~m}$ from the coastline, there were 646 buildings in 2018, 45 of which were built between 2007 and 2018 (variation of 8\%). The new buildings are, on average, lower (minus $6 \mathrm{~m}$ ), have higher exposed surface area and higher volume, have similar compactness form, have no contiguity and higher rooftop solar potential, when compared to the ones in 2007. The area between 500 and $2000 \mathrm{~m}$, is where the number of new buildings increased most $(56 \%)$. These new buildings are taller (plus $6 \mathrm{~m}$ ), with higher exposed surface area and volume, with similar compactness form, lower contiguity, and higher rooftop solar potential. The $2000 \mathrm{~m}$ beyond the coastline is where the variation is lower (4\%). In this area, the new buildings are taller (plus $14 \mathrm{~m}$ ), but with less exposed surface area, slightly more compact in form, less contiguous and with higher solar potential. Regarding buildings function, two out of three new buildings dedicated to tourist use are concentrated in the first $500 \mathrm{~m}$ from the coastline, and the remaining one is in the area between 500 and $2000 \mathrm{~m}$ from the coastline.

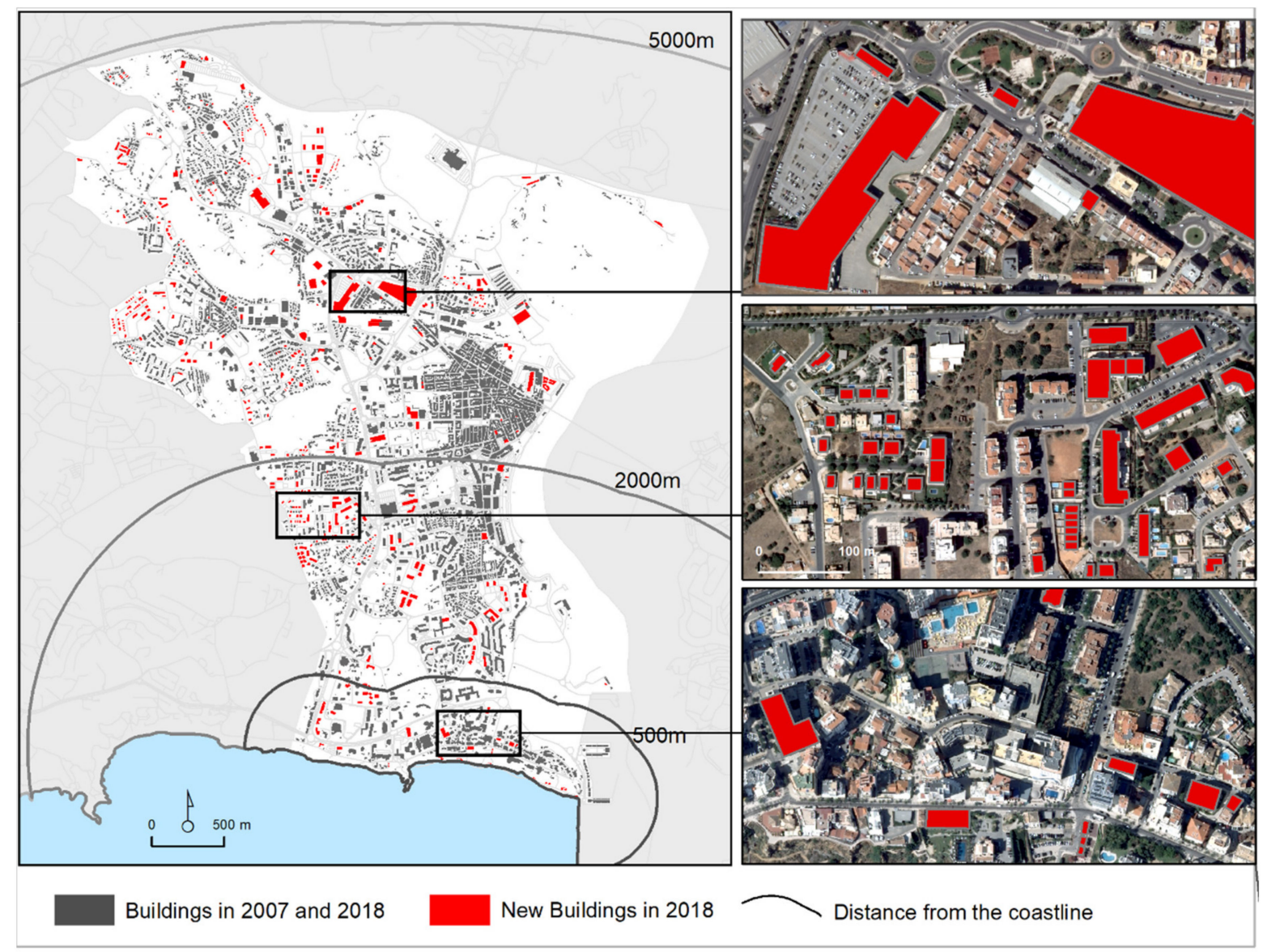

Figure 5. Urban development, in the 2007-2018 period, by distance to the coastline.

After calculating the 2D and 3D indicators at the building scale, all indicators were aggregated to the block scale and grouped considering the three strategic sustainable challenges of urban sustainability - the urban form, the solar potential, and the outdoor 
comfort. Afterwards, the variation in the Building Density and Built Volume Indicators was used to assess urban change. The variation of the indicators in the period under analysis showed that 162 out of 680 blocks changed between 2007 and 2018 ( $29 \%$ of the total blocks). For all these blocks, the building density increased, and the same occurred in the built volume, except in one block, where the new buildings had volumes slightly lower than the ones demolished. In the changed blocks, demolitions only occurred in nine blocks, where 22 buildings were dismantled and replaced by others.

Table 5. Characterization of the buildings according to the distance to the coastline and year.

\begin{tabular}{|c|c|c|c|c|c|c|c|c|}
\hline $\begin{array}{l}\text { Distance to } \\
\text { Coastline }\end{array}$ & Year & $\begin{array}{l}\text { Buildings } \\
\text { (Count) }\end{array}$ & $\begin{array}{c}\text { Average } \\
\text { Building } \\
\text { Height (m) }\end{array}$ & $\begin{array}{c}\text { Average } \\
\text { BAR }\end{array}$ & $\begin{array}{c}\text { Average } \\
\text { Building } \\
\text { Volume }\left(\mathrm{m}^{3}\right)\end{array}$ & $\begin{array}{l}\text { Average } \\
\text { 3DMassI }\end{array}$ & $\begin{array}{c}\text { Average } \\
\text { Contiguity }\end{array}$ & $\begin{array}{l}\text { Average } \\
\operatorname{RSP}\left(\mathbf{m}^{2}\right)\end{array}$ \\
\hline \multirow{4}{*}{$0-500 \mathrm{~m}$} & 2007 & 601 & 31 & 1.81 & 9396 & 0.88 & 0.18 & 92.69 \\
\hline & 2018 & 646 & 31 & 1.82 & 9705 & 0.88 & 0.17 & 95.57 \\
\hline & 2007-2018 & 45 & 25 & 1.95 & 13,832 & 0.88 & 0 & 133.96 \\
\hline & 2007 & 137 & 30 & 1.63 & 5231 & 0.93 & 0.13 & 54.39 \\
\hline \multirow{3}{*}{$500-2000 \mathrm{~m}$} & 2018 & 214 & 33 & 1.66 & 8922 & 0.93 & 0.11 & 80.84 \\
\hline & 2007-2018 & 77 & 36 & 1.7 & 15,490 & 0.93 & 0.07 & 127.9 \\
\hline & 2007 & 9532 & 29 & 1.81 & 4480 & 0.91 & 0.55 & 46.44 \\
\hline \multirow[t]{2}{*}{$2000-5000 \mathrm{~m}$} & 2018 & 9894 & 30 & 1.81 & 5016 & 0.92 & 0.53 & 50.92 \\
\hline & 2007-2018 & 362 & 43 & 1.69 & 19,117 & 0.93 & 0.01 & 168.96 \\
\hline
\end{tabular}

\subsection{Typologies of Urban Growth}

For the 162 changed blocks, the eight sustainable indicators were derived for each year and then subtracted. The variation of each indicator at the block scale was used as a variable in cluster analysis. The optimal number of clusters was evaluated by computing a pseudo F-statistic for clustering solutions with 2 through 30 clusters. The largest pseudo F-statistic values indicate solutions that perform best at maximizing both within-cluster similarities and between-cluster differences.

Based on the high value of the pseudo F-statistic, either 2 or 3 groups are discernible in our dataset (Appendix A). Therefore, the number of clusters was defined as 3 , and no spatial constraints were specified, meaning that clusters do not need to be spatially proximal.

Following the relationships identified for each indicator (Section 3.3.2), blocks with multi-familiar, narrow, contiguous and compact buildings, with increased solar potential and with sky visibility and shadows in the open space, reveal an urban development pattern towards sustainability. These criteria are assessed in each cluster, using the statistical distributions available in the boxplots (Figure 6). Based on that analysis, and to depict the major development patterns, three urban growth typologies were identified: low, medium, and high urban sustainable development.

The number of blocks in each typology is 133 (low), 10 (medium) and 19 (high) (Figure 7). The summary of clusters characteristics and their relationship with urban sustainability is as follows:

- Most of the blocks that changed between 2007 and 2018 (82\%), followed a low sustainable development. These blocks obtained low values for urban sustainable form and urban solar energy, and medium values for urban outdoor comfort.

- This cluster had the lower variation in the built volume and density, and consequently the lower variations in the roof areas with good solar exposition. The urban development also privileged single-family houses and more detached and less compact buildings, but with a comfortable thermal environment, with visible sky area and shadows in the open space.

- Only a small part of the blocks (6\%) followed a medium sustainable development pattern. These blocks showed medium values for urban sustainable form, urban solar energy, and urban outdoor comfort. 


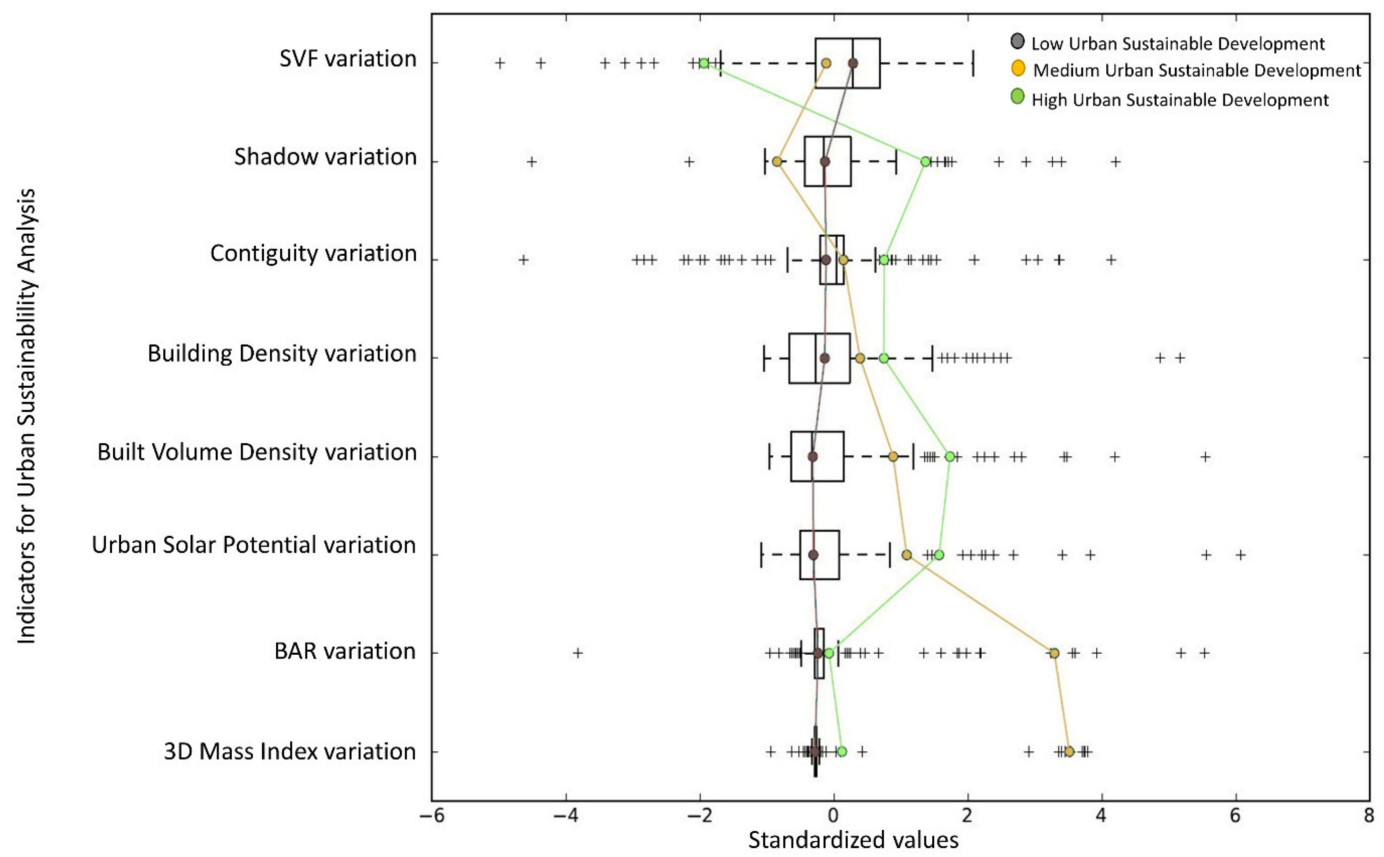

Figure 6. Boxplot of the cluster analysis that summarizes both the groups and the variables within each cluster.
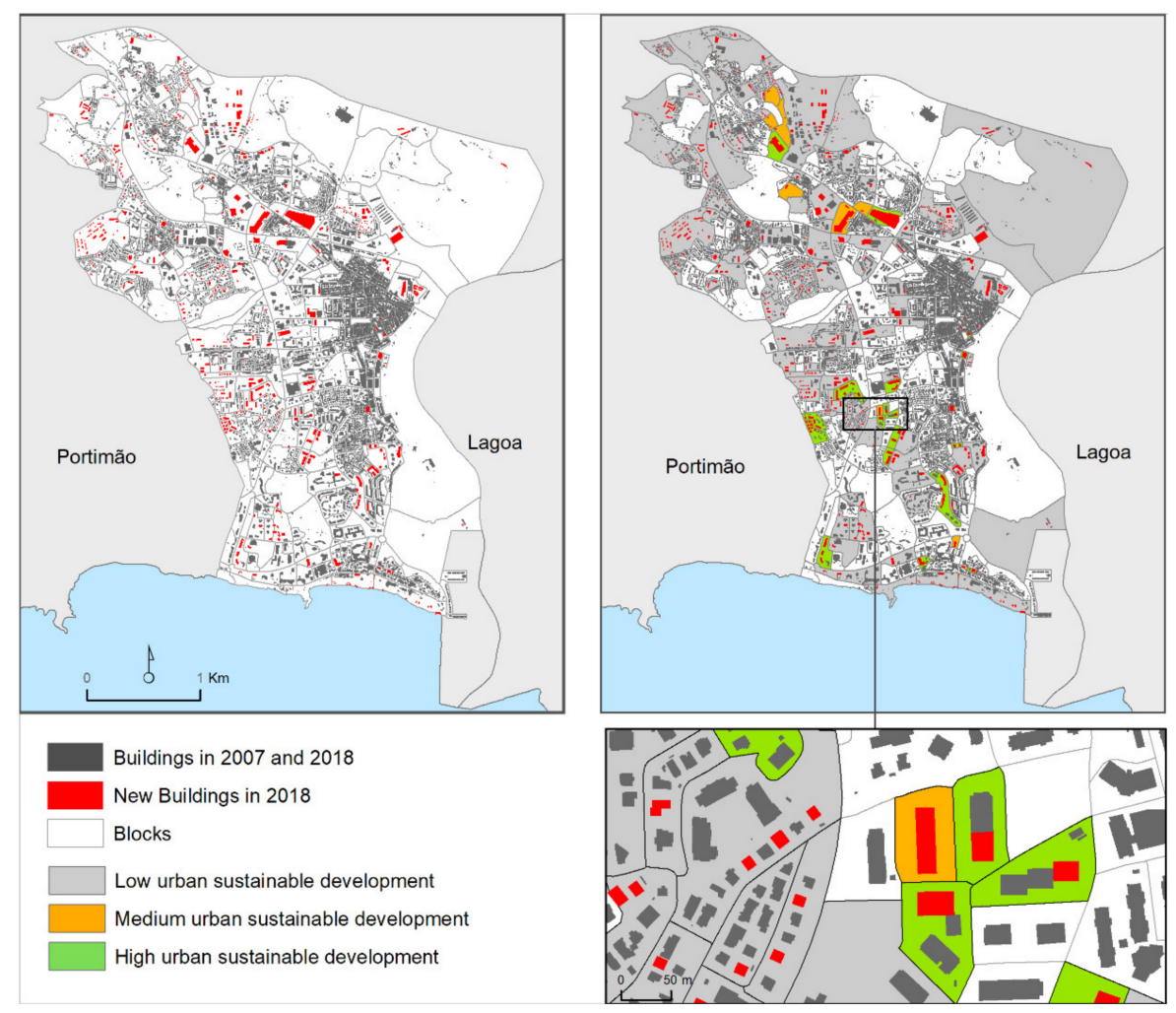

Figure 7. Map of the changed blocks between 2007 and 2018 classified according to the level of urban sustainable development.

These blocks had no construction in 2007 and in 2018 the new buildings were compact and long, with a high exposed surface area. This urban form increases the energy transfer and thus compromises urban sustainability. Furthermore, in these blocks, the shadows diminished. This is because, before construction, the block area benefited from the shading of buildings on its borders. With the new constructions, these areas of shadow disappeared, making the open space less comfortable. 
- A high sustainable development was observed in $12 \%$ of the changed blocks in the study area. These blocks had a high performance regarding urban sustainable form and urban solar energy, and a medium performance in the urban outdoor comfort.

- This cluster includes contiguous multi-familiar buildings, with rooftop areas with high solar potential, and where the open space is comfortable because of the shadows, but with a slightly diminished amount of visible sky. In two of these blocks, a single new building was built. These new buildings were a shopping mall and a retail commercial area. On the remaining blocks, the new developments included from 3-storey up to 10-storey apartments, mainly for residential use (either for second homes or short-term rental apartments).

\subsection{Implications for Urban Planning and Sustainable Development}

The results of this study have multiple implications for urban sustainability planning. First, they show that most of the new urban land area in the study area is not following a sustainable development pattern. This suggests that there is considerable opportunity to implement future patterns of sustainable urbanization. However, in these blocks, where the urban layout is established, it is difficult to introduce adjustments. This fact calls out to the need to develop strategies for sustainable urban growth based on updated geographic information.

In this way, our study shows the utility of indicators to assess the urban design. Their use can guide preliminary evaluations of urban form, energy, and outdoor comfort, and help urbanists and architects understanding the implications of different urban development patterns in terms of urban sustainability and make the necessary adjustments. Additionally, the spatialization of low sustainable development "hot-spots" can provide useful information for future planning scenarios. Such awareness can be useful to help design alternative solutions since different parts of the city may require differentiated urban growth strategies.

The analysis of the different indicators can be useful to identify in the urban landscape, which blocks have the best chances of benefit from fiscal stimulus packages, and which blocks deserve a priority intervention, as well [71]. Such an indicator-based system can also be beneficial for detecting what are the different needs in each block. For example, in those blocks with a low value of shadows in the public space, mitigation solutions include the adoption of solar control devices like street sun sails (e.g., [66]) or the promotion of street tree planting actions [72]. In blocks with low Urban Solar Potential, new constructions should include south-facing roofs with large areas to receive solar panels [37]. In blocks with low urban development patterns, prioritizing the renewal of old buildings is also a strategic option to ensure resilient and long-term development [73]. Sustainable indicators can also improve decision making and be used to analyze future growth scenarios, providing awareness of the long-term effects of urban growth, and assisting the city to achieve sustainable urban growth.

In this study, we demonstrated the utility of the sustainable indicators for studying sustainable strategic challenges such as urban form, solar energy, or outdoor comfort. Other dimensions of sustainability can also take advantage of 3D urban data. For the environmental dimension, using 3D models adds a substantial increase in the accuracy of the results and their interpretation. These include air pollution evaluation, noise propagation estimation or flood risk analysis and simulation [18,74]. Considering the socio-economic dimension, 3D models of the built environment can be used as a proxy for population density, or to assess the economic evaluation of the real estate or be used to improve the public participation process through 3D visualization of different planning alternatives [75]. 3D information is rarely used for characterizing urban development at lower scales due to data unavailability. There are only a few studies on the vertical dimension of urban structures, either at lower scales [76] or for selected cities across the globe [12,77-79]. This limitation can soon be overcome by the development of data fusion techniques for producing $3 \mathrm{D}$ spatial information from synthetic aperture radar (SAR) and optical image pairs [80]. 


\section{Conclusions}

Most previous studies have a single approach towards urban change and the sustainable development assessment-either looking into urban growth as a 2D rather than a 2D and 3D phenomenon, or by considering the effect of urban form compactness on the energy consumption, or the impact of horizontal and vertical urban growth on the land surface temperature, among others. However, for studying the urban form and sprawl, at local scales, detailed 3D information on the built environment provides better data representation and decreases uncertainty. This study goes a step forward and evaluates if urban growth can be considered as moving away or towards more sustainable development. The proposed indicators provide more information than those based only on 2D and allow re-scaling the analysis of urban development by capturing proxies of competing dimensions of sustainability. The basis for the assessment was the urban morphology and how it relates to the sustainable urban form, solar energy, and outdoor comfort. All the selected indicators are easy to apply, easy to calculate, relevant to local levels, and contribute to the achievement of the sustainable development targets. For the architects and urbanists, the indicators can be used to maximize sustainable urban layouts. For municipal technicians and policymakers, the indicators can be used for identifying priority sites for interventions and to monitor and evaluate the plans' implementation process.

The proposed methodology is straightforward and is based on information that already exists in the municipalities (building footprints and DTM), complemented with other information that can be easily acquired (DSM). The findings can be integrated into other sustainable development indicator systems, like the ecological footprint and biocapacity which allows defining environmental carrying capacity [81]. The proposed indicators can also be used to revive the Algarve Region's System of Indicators of Sustainable Development (SIDS) (https:/ / web.ccdr-alg.pt/sids, accessed 15 August 2021). This project was developed at the beginning of 2020 but is not operational because it depends on information that is collected by different entities who do not ensure the data for the system's continuity [82]. This case reveals the importance of having the data easily available or produced regularly to facilitate monitoring and evaluation. The use of remote sensingbased indicators, like the ones proposed in this study, can be an effective way to overcome these difficulties.

Some remarks about the scope of this research should be pointed out. This study misses one of the most relevant aspects of urban sustainability-the provision of the green area. In future studies, we will continue to improve the indicators by adding indicators concerning green infrastructures. These constitute a key element for cities to mitigate and adapt to climate change, attenuating its undesired impacts, such as the heat stress and the urban heat island effect. For this study, there were no reliable data sources for the initial period of analysis (2007). However, for the recent period (2018) we already have a good 2D and 3D database of the green infrastructures within the study area. This will allow to include the green dimension in the next sustainable development assessment. The environmental impacts of green areas in urban environments such as carbon sequestration, flooding control or heat stress mitigation, can all be measured in a GIS environment, and findings can contribute to the city's quality of life assessment. With this incremental approach, we aim at providing a more robust set of urban indicators to aid the local urban planning in meeting sustainable goals.

Solar potential mapping is the starting point for evaluating the dissemination of renewable energy technologies at the urban scale. Knowing the solar radiance at each building also provides useful information to estimate indoor thermal comfort (buildings exposed to much sunlight can overheat during the summer) or to improve the design of the urban layout so that the solar availability in the neighborhood is maximized. Knowing the local power generation potential can also be used to estimate the capacities of decentralized energy sources in crisis management applications [83]. Additionally, the use of other relevant variables such as structural conditions, number of occupants by dwelling 
or the income level of the households, if available, would also enrich the Urban Solar Energy indicator.

Regarding outdoor comfort, we evaluated the impact of the built environment on the provision of shadows in the open space. Although some variables are equally important to outdoor comfort studies, such as air temperature or wind velocity, or covering materials like asphalt or green cover, these were not considered in this study since it would require field measurements and local microclimate modeling which was not compatible with the work's framework or with the scale of analysis. Furthermore, other parameters influencing global human comfort like air quality, lighting, acoustics, or smell were also left out of the analysis. In future studies, the assessment of impacts such as vegetation, water, and pavement-type on the thermal comfort shall be included in the Urban Outdoor Comfort indicator.

The results depict the critical role that multi-dimensional indicators-2D data, complemented with 3D information of the urban environment—play in evaluating the sustainable development trend in the study area. This is of great potential due to the growing availability of open geographic and satellite data and derived products, covering large areas, freely or at relatively low cost. Furthermore, only by using 3D spatial models of the urban surface can the amount of solar income be determined. This information is valuable when designing sustainable cities, and can help determine local solar potential, thus promoting renewable sources of energy, but also to assess the provision of shadows, an important feature for thermal comfort of pedestrians or cyclists.

Author Contributions: Conceptualization, T.S. and R.D.; methodology, T.S. and J.R.; formal analysis, T.S. and J.R.; investigation, T.S. and R.D.; writing — original draft preparation, T.S.; writing-review and editing, T.S., R.D. and J.R.; supervision, J.A.T.; funding acquisition, T.S., R.D. and J.A.T. All authors have read and agreed to the published version of the manuscript.

Funding: This work was financed by national funds through FCT-Foundation for Science and Technology, I.P., within the scope of the project «UIDB/04647/2020» of CICS.NOVA-Centro Interdisciplinar de Ciências Sociais da Universidade Nova de Lisboa. The first author was financed by national funds through the FCT, under the Norma Transitória-DL 57/2016/CP1453/CT0004. The second author was financed by national funds through the FCT, under the Norma Transitória-DL 57/2016/CP1453/CT0105.

Conflicts of Interest: The authors declare no conflict of interest. The funders had no role in the design of the study; in the collection, analyses, or interpretation of data; in the writing of the manuscript, or in the decision to publish the results.

\section{Appendix A}

Pseudo F-Statistic Plot

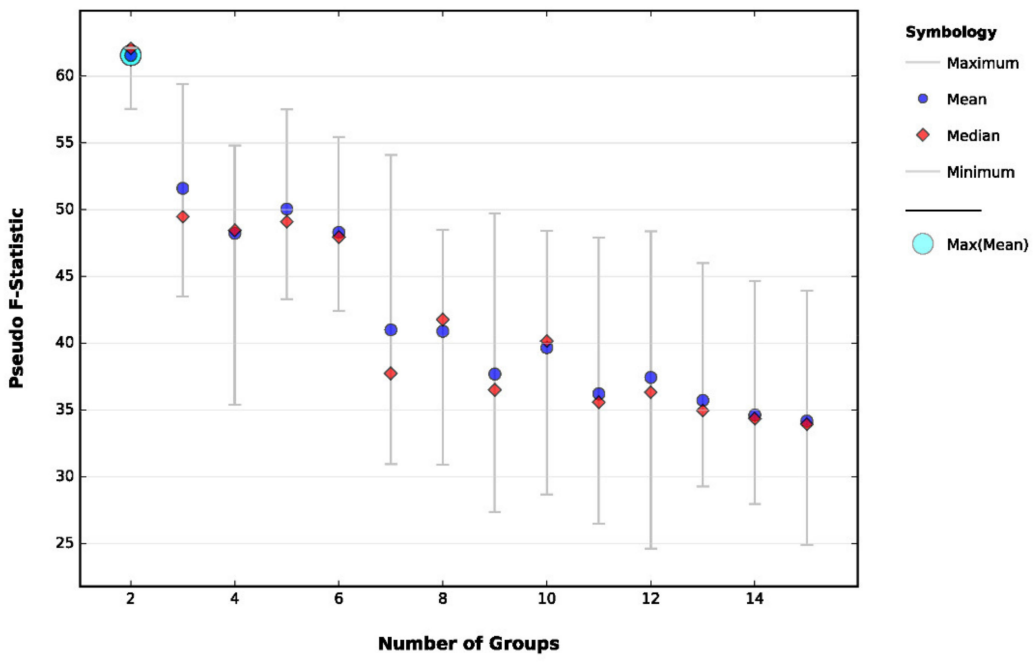




\section{References}

1. Cocchia, A. Smart and Digital City: A Systematic Literature Review. In Smart City: How to Create Public and Economic Value with High Technology in Urban Space; Dameri, R.P., Rosenthal-Sabroux, C., Eds.; Progress in IS; Springer International Publishing: Cham, Switzerland, 2014; pp. 13-43, ISBN 978-3-319-06160-3.

2. Attour, A.; Burger-Helmchen, T. Guest Editorial. J. Strategy Manag. 2015, 8. [CrossRef]

3. Deakin, M.; Waer, H.A. From Intelligent to Smart Cities. Intell. Build. Int. 2011, 3, 133-139. [CrossRef]

4. Marsal-Llacuna, M.-L. Conceptualizing, Modeling and Simulating Sustainability as Tools to Implement Urban Smartness. In Computational Science and Its Applications-ICCSA 2015; Gervasi, O., Murgante, B., Misra, S., Gavrilova, M.L., Rocha, A.M.A.C., Torre, C., Taniar, D., Apduhan, B.O., Eds.; Springer International Publishing: Cham, Switzerland, 2015; pp. 477-494.

5. United Nations Social Development for Sustainable Development I DISD. Available online: https://www.un.org/development/ desa/dspd/2030agenda-sdgs.html/ (accessed on 10 July 2021).

6. Chen, H.; Jia, B.; Lau, S.S.Y. Sustainable Urban Form for Chinese Compact Cities: Challenges of a Rapid Urbanized Economy. Habitat Int. 2008, 32, 28-40. [CrossRef]

7. Piro, R. Parallel Patterns of Shrinking Cities and Urban Growth: Spatial Planning for Sustainable Development of City Regions and Rural Areas; Routledge: London, UK, 2016; ISBN 978-1-317-08416-7.

8. Organisation for Economic Co-operation and Development. Sustainable Development Strategies: A Resource Book; Earthscan: London, UK; Sterling, VA, USA, 2002; ISBN 978-1-85383-946-7.

9. Wang, R.; Murayama, Y.; Morimoto, T. Scenario Simulation Studies of Urban Development Using Remote Sensing and GIS: Review. Remote Sens. Appl. Soc. Environ. 2021, 22, 100474. [CrossRef]

10. Alavipanah, S.; Schreyer, J.; Haase, D.; Lakes, T.; Qureshi, S. The Effect of Multi-Dimensional Indicators on Urban Thermal Conditions. J. Clean. Prod. 2018, 177, 115-123. [CrossRef]

11. Koomen, E.; Rietveld, P.; Bacao, F. The Third Dimension in Urban Geography: The Urban-Volume Approach. Environ. Plan. B Plan. Des. 2009, 36, 1008-1025. [CrossRef]

12. Mahtta, R.; Mahendra, A.; Seto, K.C. Building up or Spreading out? Typologies of Urban Growth across 478 Cities of 1 Million Plus. Environ. Res. Lett. 2019, 14, 124077. [CrossRef]

13. Qiao, W.; Wang, Y.; Ji, Q.; Hu, Y.; Ge, D.; Cao, M. Analysis of the Evolution of Urban Three-Dimensional Morphology: The Case of Nanjing City, China. J. Maps 2019, 15, 30-38. [CrossRef]

14. Shirowzhan, S.; Trinder, J.; Osmond, P. New Metrics for Spatial and Temporal 3D Urban Form Sustainability Assessment Using Time Series Lidar Point Clouds and Advanced GIS Techniques. Sustain. Urban Plan. Des. 2019. [CrossRef]

15. Zhao, C.; Weng, Q.; Hersperger, A.M. Characterizing the 3-D Urban Morphology Transformation to Understand Urban-Form Dynamics: A Case Study of Austin, Texas, USA. Landsc. Urban Plan. 2020, 203, 103881. [CrossRef]

16. Koziatek, O.; Dragićević, S. A Local and Regional Spatial Index for Measuring Three-Dimensional Urban Compactness Growth. Environ. Plan. B Urban Anal. City Sci. 2019, 46, 143-164. [CrossRef]

17. Stal, C.; Tack, F.; Maeyer, P.D.; Wulf, A.D.; Goossens, R. Airborne Photogrammetry and Lidar for DSM Extraction and 3D Change Detection over an Urban Area-A Comparative Study. Int. J. Remote Sens. 2013, 34, 1087-1110. [CrossRef]

18. Biljecki, F.; Stoter, J.; Ledoux, H.; Zlatanova, S.; Çöltekin, A. Applications of 3D City Models: State of the Art Review. ISPRS Int. J. Geo-Inf. 2015, 4, 2842-2889. [CrossRef]

19. Wu, C.-D.; Lung, S.-C.C. Application of 3-D Urbanization Index to Assess Impact of Urbanization on Air Temperature. Sci. Rep. 2016, 6, 24351. [CrossRef]

20. Wang, S.; Tian, Y.; Zhou, Y.; Liu, W.; Lin, C. Fine-Scale Population Estimation by 3D Reconstruction of Urban Residential Buildings. Sensors 2016, 16, 1755. [CrossRef]

21. El-Hallaq, M.A.; Alastal, A.I.; Salha, R.A. Enhancing Sustainable Development through Web Based 3D Smart City Model Using GIS and BIM. Case Study: Sheikh Hamad City. J. Geogr. Inf. Syst. 2019, 11, 321-330. [CrossRef]

22. Hu, Y.; Dai, Z.; Guldmann, J.-M. Modeling the Impact of 2D/3D Urban Indicators on the Urban Heat Island over Different Seasons: A Boosted Regression Tree Approach. J. Environ. Manag. 2020, 266, 110424. [CrossRef]

23. Hiremath, R.B.; Balachandra, P.; Kumar, B.; Bansode, S.S.; Murali, J. Indicator-Based Urban Sustainability-A Review. Energy Sustain. Dev. 2013, 17, 555-563. [CrossRef]

24. Morganti, M.; Salvati, A.; Coch, H.; Cecere, C. Urban Morphology Indicators for Solar Energy Analysis. Energy Procedia 2017, 134, 807-814. [CrossRef]

25. Ali-Toudert, F.; Mayer, H. Effects of Asymmetry, Galleries, Overhanging Façades and Vegetation on Thermal Comfort in Urban Street Canyons. Sol. Energy 2007, 81, 742-754. [CrossRef]

26. Bartesaghi-Koc, C.; Haddad, S.; Pignatta, G.; Paolini, R.; Prasad, D.; Santamouris, M. Can Urban Heat Be Mitigated in a Single Urban Street? Monitoring, Strategies, and Performance Results from a Real Scale Redevelopment Project. Sol. Energy 2021, 216, 564-588. [CrossRef]

27. Ng, E.; Yuan, C.; Chen, L.; Ren, C.; Fung, J.C.H. Improving the Wind Environment in High-Density Cities by Understanding Urban Morphology and Surface Roughness: A Study in Hong Kong. Landsc. Urban Plan. 2011, 101, 59-74. [CrossRef]

28. Hang, J.; Sandberg, M.; Li, Y. Effect of Urban Morphology on Wind Condition in Idealized City Models. Atmos. Environ. 2009, 43, 869-878. [CrossRef] 
29. Ariza-Villaverde, A.B.; Jiménez-Hornero, F.J.; Gutiérrez De Ravé, E. Influence of Urban Morphology on Total Noise Pollution: Multifractal Description. Sci. Total. Environ. 2014, 472, 1-8. [CrossRef]

30. Cariolet, J.-M.; Colombert, M.; Vuillet, M.; Diab, Y. Assessing the Resilience of Urban Areas to Traffic-Related Air Pollution: Application in Greater Paris. Sci. Total. Environ. 2018, 615, 588-596. [CrossRef]

31. Rode, P.; Keim, C.; Robazza, G.; Viejo, P.; Schofield, J. Cities and Energy: Urban Morphology and Residential Heat-Energy Demand. Environ. Plan. B Plan. Des. 2014, 41, 138-162. [CrossRef]

32. Lee, J.M.; Braham, W. Right-Sizing Cities for Maximum Power: Urban Form Parameters for New York City and the Greater Philadelphia Region. Sustainability 2019, 11, 2352. [CrossRef]

33. Chen, H.-C.; Han, Q.; de Vries, B. Urban Morphology Indicator Analyzes for Urban Energy Modeling. Sustain. Cities Soc. 2020, 52, 101863. [CrossRef]

34. Rosales Carreón, J.; Worrell, E. Urban Energy Systems within the Transition to Sustainable Development. A Research Agenda for Urban Metabolism. Resour. Conserv. Recycl. 2018, 132, 258-266. [CrossRef]

35. Arroyo, M.F.R.; Miguel, L.J. The Role of Renewable Energies for the Sustainable Energy Governance and Environmental Policies for the Mitigation of Climate Change in Ecuador. Energies 2020, 13, 3883. [CrossRef]

36. Wang, P.; Liu, Z.; Zhang, L. Sustainability of Compact Cities: A Review of Inter-Building Effect on Building Energy and Solar Energy Use. Sustain. Cities Soc. 2021, 72, 103035. [CrossRef]

37. Santos, T.; Gomes, N.; Freire, S.; Brito, M.C.; Santos, L.; Tenedório, J.A. Applications of Solar Mapping in the Urban Environment. Appl. Geogr. 2014, 51, 48-57. [CrossRef]

38. Barragán-Escandón, A.; Zalamea-León, E.; Terrados-Cepeda, J. Incidence of Photovoltaics in Cities Based on Indicators of Occupancy and Urban Sustainability. Energies 2019, 12, 810. [CrossRef]

39. Mainzer, K.; Killinger, S.; McKenna, R.; Fichtner, W. Assessment of Rooftop Photovoltaic Potentials at the Urban Level Using Publicly Available Geodata and Image Recognition Techniques. Sol. Energy 2017, 155, 561-573. [CrossRef]

40. Martins, T.A.; Adolphe, L.; Bastos, L.E. From Solar Constraints to Urban Design Opportunities: Optimization of Built Form Typologies in a Brazilian Tropical City. Energy Build. 2014, 76, 43-56. [CrossRef]

41. Chatzipoulka, C.; Compagnon, R.; Nikolopoulou, M. Urban Geometry and Solar Availability on Façades and Ground of Real Urban Forms: Using London as a Case Study. Sol. Energy 2016, 138, 53-66. [CrossRef]

42. Mohajeri, N.; Upadhyay, G.; Gudmundsson, A.; Assouline, D.; Kämpf, J.; Scartezzini, J.-L. Effects of Urban Compactness on Solar Energy Potential. Renew. Energy 2016, 93, 469-482. [CrossRef]

43. Sarralde, J.J.; Quinn, D.J.; Wiesmann, D.; Steemers, K. Solar Energy and Urban Morphology: Scenarios for Increasing the Renewable Energy Potential of Neighbourhoods in London. Renew. Energy 2015, 73, 10-17. [CrossRef]

44. Zhang, J.; Xu, L.; Shabunko, V.; Tay, S.E.R.; Sun, H.; Lau, S.S.Y.; Reindl, T. Impact of Urban Block Typology on Building Solar Potential and Energy Use Efficiency in Tropical High-Density City. Appl. Energy 2019, 240, 513-533. [CrossRef]

45. Abdollahzadeh, N.; Biloria, N. Outdoor Thermal Comfort: Analyzing the Impact of Urban Configurations on the Thermal Performance of Street Canyons in the Humid Subtropical Climate of Sydney. Front. Archit. Res. 2021, 10, 394-409. [CrossRef]

46. Kumar, P.; Sharma, A. Study on Importance, Procedure, and Scope of Outdoor Thermal Comfort-A Review. Sustain. Cities Soc. 2020, 61, 102297. [CrossRef]

47. Lin, T.-P.; Matzarakis, A.; Hwang, R.-L. Shading Effect on Long-Term Outdoor Thermal Comfort. Build. Environ. 2010, 45, $213-221$. [CrossRef]

48. Oke, T.R.; Johnson, G.T.; Steyn, D.G.; Watson, I.D. Simulation of Surface Urban Heat Islands under 'Ideal' Conditions at Night Part 2: Diagnosis of Causation. Bound. Layer Meteorol. 1991, 56, 339-358. [CrossRef]

49. Zhang, J.; Heng, C.K.; Malone-Lee, L.C.; Hii, D.J.C.; Janssen, P.; Leung, K.S.; Tan, B.K. Evaluating Environmental Implications of Density: A Comparative Case Study on the Relationship between Density, Urban Block Typology and Sky Exposure. Autom. Constr. 2012, 22, 90-101. [CrossRef]

50. Zwolinski, A.; Jarzemski, M. Computing and Monitoring Potential of Public Spaces by Shading Analysis Using 3d Lidar Data and Advanced Image Analysis. Int. Arch. Photogramm. Remote Sens. Spat. Inf. Sci. 2015, 40, 743-750. [CrossRef]

51. Yang, X.; Li, Y. The Impact of Building Density and Building Height Heterogeneity on Average Urban Albedo and Street Surface Temperature. Build. Environ. 2015, 90, 146-156. [CrossRef]

52. Yu, Z.; Chen, S.; Wong, N.H. Temporal Variation in the Impact of Urban Morphology on Outdoor Air Temperature in the Tropics: A Campus Case Study. Build. Environ. 2020, 181, 107132. [CrossRef]

53. Ahmadi Venhari, A.; Tenpierik, M.; Taleghani, M. The Role of Sky View Factor and Urban Street Greenery in Human Thermal Comfort and Heat Stress in a Desert Climate. J. Arid. Environ. 2019, 166, 68-76. [CrossRef]

54. Turismo de Portugal Estatísticas I Taxa de Sazonalidade 2015-2018. Available online: http://travelbi.turismodeportugal.pt/enus/Pages/PowerBI/Sustentabilidade/seasonality-rate.aspx (accessed on 16 April 2021).

55. Magarotto, M.G.; Tenedório, J.A.; da Costa, M.F.; Calor, I.; da Silva, C.P. Analysis of Urban Growth in Coastal Areas Supported by 2D/2.5D GIS Data. A Comparative Study of Boa Viagem Beach (Brazil) and Rocha Beach (Portugal). J. Coast. Conserv. 2019, 23, 1081-1091. [CrossRef]

56. De Deus, R.F.; Tenedório, J.A.; Bergadà, M.M. Urban Sprawl in Portugal Based on Urban Systems Spatial Boundaries. ACE Archit. City Environ. 2012, 7, 131-148. 
57. De Deus, R.F.; Tenedório, J.A.; Rocha, J. Modelling Land-Use and Land-Cover Changes: A Hybrid Approach to a Coastal Area. In Methods and Applications of Geospatial Technology in Sustainable Urbanism; IGI Global: Hershey, PA, USA, 2021; pp. 57-102. ISBN 9781799822493.

58. Trimble Match-t Dsm Inpho Software. Available online: http://trl.trimble.com/docushare/dsweb/Get/Document-696437/022 516-018C_Inpho_MATCH-T_DSM_TS_USL_0516_LR.pdf (accessed on 31 May 2021).

59. McKeen, P.; Fung, A.S. The Effect of Building Aspect Ratio on Energy Efficiency: A Case Study for Multi-Unit Residential Buildings in Canada. Buildings 2014, 4, 336-354. [CrossRef]

60. Intergovernmental Panel on Climate Change Climate Change 2014 Mitigation of Climate Change: Working Group III Contribution to the Fifth Assessment Report of the Intergovernmental Panel on Climate Change; Cambridge University Press: Cambridge, UK, 2014; ISBN 978-1-107-41541-6.

61. Resch, E.; Bohne, R.A.; Kvamsdal, T.; Lohne, J. Impact of Urban Density and Building Height on Energy Use in Cities. Energy Procedia 2016, 96, 800-814. [CrossRef]

62. Fu, P.; Rich, P.M. Design and Implementation of the Solar Analyst: An ArcView Extension for Modeling Solar Radiation at Landscape Scales. In Proceedings of the Nineteenth Annual ESRI User Conference, San Diego, CA, USA, 26-30 July 1999; Volume 1, pp. 1-31.

63. Dirksen, M.; Ronda, R.J.; Theeuwes, N.E.; Pagani, G.A. Sky View Factor Calculations and Its Application in Urban Heat Island Studies. Urban Clim. 2019, 30, 100498. [CrossRef]

64. Choi, Y.; Lee, S.; Moon, H. Urban Physical Environments and the Duration of High Air Temperature: Focusing on Solar Radiation Trapping Effects. Sustainability 2018, 10, 4837. [CrossRef]

65. Bernard, J.; Bocher, E.; Petit, G.; Palominos, S. Sky View Factor Calculation in Urban Context: Computational Performance and Accuracy Analysis of Two Open and Free GIS Tools. Climate 2018, 6, 60. [CrossRef]

66. Garcia-Nevado, E.; Duport, N.; Bugeat, A.; Beckers, B. Benefits of Street Sun Sails to Limit Building Cooling Needs in a Mediterranean City. Build. Environ. 2021, 187, 107403. [CrossRef]

67. Jabareen, Y.R. Sustainable Urban Forms: Their Typologies, Models, and Concepts. J. Plan. Educ. Res. 2006, 26, 38-52. [CrossRef]

68. Mouratidis, K. Built Environment and Social Well-Being: How Does Urban Form Affect Social Life and Personal Relationships? Cities 2018, 74, 7-20. [CrossRef]

69. Makido, Y.; Dhakal, S.; Yamagata, Y. Relationship between Urban Form and $\mathrm{CO}_{2}$ Emissions: Evidence from Fifty Japanese Cities. Urban Clim. 2012, 2, 55-67. [CrossRef]

70. Decreto-Lei 80/2006. 4 April 2006. Available online: https://dre.pt/home/-/dre/672456/details/maximized (accessed on 10 July 2021).

71. Santos, T.; Tenedório, J.A.; Gonçalves, J.A. Quantifying the City's Green Area Potential Gain Using Remote Sensing Data. Sustainability 2016, 8, 1247. [CrossRef]

72. Santos, T.; Silva, C.; Tenedório, J.A. Promoting Citizens' Quality of Life through Green Urban Planning. In Geographical Information Systems Theory, Applications and Management; Ragia, L., Laurini, R., Rocha, J.G., Eds.; Communications in Computer and Information Science; Springer International Publishing: Cham, Switzerland, 2019; pp. 153-175, ISBN 978-3-030-06010-7.

73. Almeida, C.P.; Ramos, A.F.; Silva, J.M. Sustainability Assessment of Building Rehabilitation Actions in Old Urban Centres. Sustain. Cities Soc. 2018, 36, 378-385. [CrossRef]

74. Stoter, J.; de Kluijver, H.; Kurakula, V. 3D Noise Mapping in Urban Areas. Int. J. Geogr. Inf. Sci. 2008, 22, 907-924. [CrossRef]

75. Herbert, G.; Chen, X. A Comparison of Usefulness of 2D and 3D Representations of Urban Planning. Cartogr. Geogr. Inf. Sci. 2015, 42, 22-32. [CrossRef]

76. Li, M.; Koks, E.; Taubenböck, H.; van Vliet, J. Continental-Scale Mapping and Analysis of 3D Building Structure. Remote Sens. Environ. 2020, 245, 111859. [CrossRef]

77. Mathews, A.J.; Frazier, A.E.; Nghiem, S.V.; Neumann, G.; Zhao, Y. Satellite Scatterometer Estimation of Urban Built-up Volume: Validation with Airborne Lidar Data. Int. J. Appl. Earth Obs. Geoinf. 2019, 77, 100-107. [CrossRef]

78. Geiß, C.; Leichtle, T.; Wurm, M.; Pelizari, P.A.; Standfuß, I.; Zhu, X.X.; So, E.; Siedentop, S.; Esch, T.; Taubenböck, H. Large-Area Characterization of Urban Morphology-Mapping of Built-Up Height and Density Using TanDEM-X and Sentinel-2 Data. IEEE J. Sel. Top. Appl. Earth Obs. Remote Sens. 2019, 12, 2912-2927. [CrossRef]

79. Esch, T.; Zeidler, J.; Palacios-Lopez, D.; Marconcini, M.; Roth, A.; Mönks, M.; Leutner, B.; Brzoska, E.; Metz-Marconcini, A.; Bachofer, F.; et al. Towards a Large-Scale 3D Modeling of the Built Environment-Joint Analysis of TanDEM-X, Sentinel-2 and Open Street Map Data. Remote Sens. 2020, 12, 2391. [CrossRef]

80. Bagheri, H.; Schmitt, M.; d'Angelo, P.; Zhu, X.X. A Framework for SAR-Optical Stereogrammetry over Urban Areas. ISPRS J. Photogramm. Remote Sens. 2018, 146, 389-408. [CrossRef]

81. Świąder, M.; Szewrański, S.; Kazak, J.K. Environmental Carrying Capacity Assessment-The Policy Instrument and Tool for Sustainable Spatial Management. Front. Environ. Sci. 2020, 8. [CrossRef]

82. Farinha, F.; Oliveira, M.J.; Silva, E.M.J.; Lança, R.; Pinheiro, M.D.; Miguel, C. Selection Process of Sustainable Indicators for the Algarve Region-OBSERVE Project. Sustainability 2019, 11, 444. [CrossRef]

83. Aarsen, R.; Janssen, M.; Ramkisoen, M.; Biljecki, F.; Quak, W.; Verbree, E. Installed base registration of decentralised solar panels with applications in crisis management. In The International Archives of the Photogrammetry, Remote Sensing and Spatial Information Sciences; Copernicus GmbH: Göttingen, Germany, 2015; Volume XL-3/W3, pp. 219-223. 